\title{
Progranulin and diabetic kidney disease
}

\author{
Bruna Bellincanta Nicoletto*, Thaiana Cirino Krolikowski, Luis Henrique Santos Canani \\ From 20th Brazilian Diabetes Society Congress \\ Porto Alegre, Brazil. 11-18 November 2015
}

\section{Background}

Progranulin (PGRN) is expressed in many cell types, including adipocytes. It has been recognized as an adipokine related to obesity, insulin resistance and type 2 diabetes mellitus (T2D) and its levels depend on kidney function. However, the association of PGRN with diabetic kidney disease remains unknown.

\section{Objective}

To evaluate serum and urinary levels of PGRN in patients with T2D and chronic kidney disease (CKD) stages 3-5 and compare to patients with T2D and glomerular filtration rate (GFR; CKD-EPI) $>60 \mathrm{~mL} / \mathrm{min}$ and with control individuals without T2D.

\section{Materials and methods}

Case-control study. Cases were defined by the presence of T2D and CKD stages 3-5, evaluated by estimated GFR $<60 \mathrm{~mL} / \mathrm{min}$, and controls were formed by patients with T2D and GFR $>60 \mathrm{~mL} / \mathrm{min}$ (diabetic control group); and by individuals without T2D (non-diabetic control group). PGRN was determined with enzyme-linked immunosorbent assay in blood and urine samples after overnight fasting. The study groups were compared by ANOVA with Tukey or Kruskal-Wallis with Dunn tests for continuous and $\chi 2$ test for categorical variables. The Spearman's correlation coefficient was used. This study was approved by the Ethics Committee of Hospital involved, and all subjects signed the informed consent.

\section{Results}

114 patients were included ( 25 at case group; 67 at T2D control group and 22 at non-diabetic control group). There were no differences in age, gender, ethnicity and body mass index (BMI) between groups. PGRN serum levels were increased in patients with T2D and CKD stages 3-5, when compared to control groups (cases:

* Correspondence: brunanicoletto@gmail.com UFRGS, Porto Alegre, Brazil
$71.97 \pm 21.75$ vs. T2D control group: $57.39 \pm 17.99$ and non-diabetic control group: $50.41 \pm 12.17 \mathrm{ng} / \mathrm{dL}$; $\mathrm{p}<0.001)$. On the other hand, urinary PGRN was decreased in cases compared to T2D control group [cases: 10.62 (6.28-14.62) vs. T2D control group: 16.58 (10.15-24.11); non-diabetic control group: 13.51 (8.2823.67) $\mathrm{ng} / \mathrm{dL} ; \mathrm{p}=0.014]$. There was a positive correlation between serum PGRN and BMI $(r=0.246 ; p=0.008)$, waist circumference $(r=0.236 ; p=0.012)$; ultra-sensitive $C$ reactive protein $(\mathrm{r}=0.372 ; \mathrm{p}<0.001)$ and interleukin -6 $(\mathrm{r}=0.350 ; \mathrm{p}<0.001)$ and a negative correlation with GFR $(r=-0.242 ; \mathrm{p}=0.010)$ in all patients. Urinary PGRN was positively associated to urinary albumin excretion $(\mathrm{r}=0.256 ; \mathrm{p}=0.007)$.

\section{Conclusion}

PGRN serum levels seems to be a marker of obesity and inflammatory state that is affected by decrease in GFR; while urinary PGRN could be a marker of diabetic kidney disease.

Published: 11 November 2015

doi:10.1186/1758-5996-7-S1-A13

Cite this article as: Nicoletto et al:: Progranulin and diabetic kidney disease. Diabetology \& Metabolic Syndrome 2015 7(Suppl 1):A13.

Submit your next manuscript to BioMed Central and take full advantage of:

- Convenient online submission

- Thorough peer review

- No space constraints or color figure charges

- Immediate publication on acceptance

- Inclusion in PubMed, CAS, Scopus and Google Scholar

- Research which is freely available for redistribution 